Stanisław Bożyk

Uniwersytet $w$ Biatymstoku

\title{
BEZPOŚREDNIE WYBORY PREMIERA W SYSTEMIE KONSTYTUCYJNYM IZRAELA (1992-2001)
}

\section{Konstytucyjne podstawy ustroju Państwa Izrael}

System konstytucyjny Państwa Izrael ukształtowany został pod znaczącym wpływem brytyjskiego wzorca ustrojowego i brytyjskich konwenansów konstytucyjnych. ${ }^{1}$ Poza tym na ostateczny kształt ustroju politycznego tego państwa wywarły również wpływ niektóre rozwiązania ustrojowe stosowane w innych demokracjach europejskich oraz w Stanach Zjednoczonych Ameryki. W konsekwencji wykształcił się w Izraelu oryginalny system prawnoustrojowy, który charakteryzuje się m.in. brakiem kompleksowej oraz systematycznej regulacji wszystkich podstawowych materii konstytucyjnych. ${ }^{2}$

Izrael jest jednym z nielicznych państw współczesnych, które nie posiada konstytucji pisanej w formie aktu normatywnego o najwyższej mocy prawnej, regulującego podstawowe zasady oraz instytucje ustroju państwowego. ${ }^{3}$ Podstawę systemu konstytucyjnego Izraela stanowi aktualnie 11 ustaw zasadniczych, ${ }^{4}$ nie uwzględniających jednak w swej treści kilku nader istotnych kwestii ustrojowych. Nie zawierają

$1 \quad$ Przesądził o tym w decydującym stopniu fakt, że do maja 1948 r. na terytorium mandatowym w Palestynie obowiązywały regulacje prawne oparte na ogólnych zasadach ustawodawstwa brytyjskiego, które w znacznej części zachowały moc obowiązującą także po utworzeniu Państwa Izrael. Por. L. Wolf-Phillips, The Westminster Model in Israel, „Parliamentary Affairs” $1973 \mathrm{nr} 26, \mathrm{s.} 415$ i n.

2 Por. S. Navot, Constitutional Law of Israel, Alphen aan den Rijn 2007, s. 83 i n.

$3 \quad$ Z opracowywania jednego aktu konstytucyjnego zrezygnowano już po upływie dwóch lat od chwili utworzenia Izraela, gdy okazało się, że nie będzie możliwe osiągnięcie porozumienia w kwestii ostatecznego kształtu ustawy zasadniczej przez wszystkie liczące się wtedy ugrupowania polityczne. Stało się tak w konsekwencji przyjęcia przez Kneset w dniu 13 czerwca 1950 r. tzw. uchwały Harariego, wprowadzającej zasadę tworzenia przyszłej konstytucji etapami, przez uchwalanie kolejno poszczególnych jej rozdziałów. Każdy taki rozdział przewidziany został w postaci zupełnie odrębnej ustawy zasadniczej, stanowionej przez Kneset jedynie zwykłą większością głosów deputowanych. Szerzej o przyczynach podjęcia takiej decyzji przez izraelski parlament zob. G. Gross, The Constitutional Question in Israel, (w:) D. J. Elazar (red.), Constitutionalism. The Israeli and American Experiences, Jerusalem 1990, s. 53 in.

4 Ponadto do podstawowych aktów ustrojowych, nie mających jednak charakteru ustaw zasadniczych, izraelska nauka prawa konstytucyjnego zalicza Deklarację Niepodległości z 1948 r., jak też niektóre ustawy zwykłe. Zob. A. Rubinstein, HaMishpat Hakonstitutionali shel Medinat Israel (The Constitutional Law of the State of Israel), Jerusalem 1992 (hebr.). 
one zwłaszcza sformułowanych expressis verbis zasad ustroju politycznego. Dotyczy to nawet tak fundamentalnych dla każdego systemu ustrojowego rozstrzygnięć, jak określenie suwerena oraz wskazanie zasadniczych form sprawowania władzy najwyższej w państwie. ${ }^{5}$

Analiza rozwiązań prawnoustrojowych, które zostały przyjęte w obowiązujących ustawach zasadniczych, pozwala na stwierdzenie, że u podstaw organizacji władz publicznych Izraela legła idea suwerenności narodu. Wynikała ona jednoznacznie już z postanowień Deklaracji Niepodległości, w której stwierdzono: „My, członkowie Rady Narodowej, ${ }^{6}$ przedstawiciele społeczności żydowskiej, niniejszym proklamujemy utworzenie państwa żydowskiego". W tej formule wspomniano, co prawda, jedynie o narodzie żydowskim, ale w tym samym akcie zadeklarowana została również zasada pełnej równości praw politycznych wszystkich mieszkańców Izraela, m.in. bez względu na przynależność narodowościową oraz wyznawaną religię. Suwerenem stał się więc de facto cały naród zamieszkujący terytorium Izraela, nie wyłączając obywateli tego państwa reprezentujących mniejszość arabską. ${ }^{7}$ Do roli jedynego przedstawicielstwa całego narodu wyznaczono jednoizbowy parlament (Kneset), ${ }^{8}$ którego skład powoływany był od początku w wyborach powszechnych i bezpośrednich. Przyjęta w 1958 r. Ustawa zasadnicza o Knesecie gwarantuje do dziś ogółowi obywateli Izraela zarówno prawo decydowania o obliczu politycznym parlamentu, jak też prawo ubiegania się o mandaty deputowanych w tym najwyższym organie przedstawicielskim.

Z treści ukształtowanych regulacji ustrojowych wynika, że władza najwyższa w Izraelu sprawowana jest przez suwerena praktycznie tylko w ramach instytucjonalnej demokracji przedstawicielskiej, czyli za pośrednictwem powoływanych podczas wyborów powszechnych posłów do Knesetu. ${ }^{9}$ Uczestniczący w wyborach

W niniejszym opracowaniu korzystam głównie z tekstów ustaw zasadniczych Izraela w języku angielskim zamieszczonych w zbiorze The Constitution of the State of Israel 1996-5756, Jerusalem 1996. Najnowsze poprawki do tych aktów zaczerpnąłem z oficjalnego serwisu internetowego Knesetu http://www.knesset.gov.il (data dostępu: 14.05.2014 r.).

6 Rada Narodowa została wyłoniona wiosną 1948 r. jako tymczasowy organ przedstawicielski, reprezentujący różne żydowskie organizacje polityczne. To na posiedzeniu tej Rady w Tel Awiwie 14 maja 1948 r. uchwalona została izraelska Deklaracja Niepodległości.

7 Por. m. in. S. Navot, Constitutional Law..., op. cit., s. 251 i n.; A. L. Bendor, The Constitutional Significante of the Jewishness of Israel, (w:) F. Oz-Salzberger, Y. Stern (red.), The Israeli Nation-State: Political, Constitutional and Cultural Challenges, Boston 2014, s. 118 i n.

8 Pierwszym ogólnonarodowym przedstawicielstwem Izraela było Zgromadzenie Konstytucyjne, którego skład (120 deputowanych) wyłoniony został w wyborach powszechnych i bezpośrednich w styczniu 1949 r. Zadaniem tej konstytuanty było przygotowanie i uchwalenie konstytucji dla nowo utworzonego Państwa Izrael. Już podczas pierwszego posiedzenia Zgromadzenia Konstytucyjnego w dniu 16 lutego 1949 r. uchwalona została Ustawa przejściowa, regulująca tymczasowo strukturę najwyższych organów państwowych. Na mocy przepisów tego aktu ustawodawczego Zgromadzenie Konstytucyjne przemianowano na Kneset i pod taką nazwą (nawiązującą do używanego w dawnym państwie żydowskim - od V do II w. p.n.e. - określenia naczelnej rady religijnej) funkcjonuje do dzisiaj najwyższy organ przedstawicielski Izraela. Por. S. Bożyk, System konstytucyjny Izraela, Warszawa 2002, s. 19 i n.

9 Poza przedstawicielską formą sprawowania najwyższej władzy w państwie, izraelskie ustawy zasadnicze nie przewidują innych postaci uczestnictwa suwerena (narodu) w podejmowaniu decyzji o szczególnym znaczeniu dla państwa lub obywateli. Wydaje się jednak, że nie wyklucza to całkowicie ewentualności wykorzystywania in- 
obywatele przesądzają przy tym nie tylko o składzie politycznym parlamentu, ale wywierają też pośredni wpływ na skład ekipy rządowej i kierunki realizowanej później przez większość rządową polityki wewnętrznej i zagranicznej. W konsekwencji szczególnie istotne znaczenie posiada zastosowanie w praktyce ustrojowej reguły przewidującej, że sprawujący typowe funkcje wykonawcze rząd ponosi polityczną odpowiedzialność przed pochodzącym z wyborów organem przedstawicielskim. Nie ulega bowiem wątpliwości, że przyjęcie i konsekwentne stosowanie tej zasady stwarza określoną gwarancję poszanowania woli wyborców, wyrażonej przez nich w akcie głosowania podczas wyborów parlamentarnych.

\section{Wybory do Knesetu}

Od chwili proklamowania niepodległości Kneset, przez niemal 50 lat, był jedynym naczelnym organem państwowym Izraela wyłanianym bezpośrednio przez ogół obywateli. ${ }^{10} \mathrm{~W}$ wyborach parlamentarnych czynne prawo wyborcze przyznane zostało obywatelom Izraela po ukończeniu 18 lat, bierne zaś po osiągnięciu 21. roku życia. ${ }^{11}$ Biernego prawa wyborczego nie otrzymały jedynie osoby pozbawione tego prawa przez sąd, jak również osoby skazane za przestępstwo przeciwko bezpieczeństwu państwa na karę co najmniej pięciu lat pozbawienia wolności. Ciekawym rozwiązaniem było zaś przyjęcie formuły tzw. „ograniczenia” biernego prawa wyborczego, obejmującej jednak wyłącznie tych posłów do Knesetu, którzy w trakcie kadencji zdecydowali się na wystąpienie $\mathrm{z}$ własnej frakcji parlamentarnej. W takim wypadku nie mogą oni kandydować w kolejnych wyborach z list wyborczych partii posiadających frakcje parlamentarne w Knesecie upływającej kadencji. ${ }^{12}$

W art. 4 Ustawy zasadniczej o Knesecie sformułowano zasadę, że skład Knesetu ma być wybierany w wyborach ogólnokrajowych. Oznacza to, że podczas wyborów parlamentarnych terytorium całego państwa stanowi jeden okręg wyborczy, a tym samym wszystkich 120 deputowanych wybiera się wyłącznie z ogólnokrajowych list kandydatów. Brak podziału kraju na okręgi wyborcze można było od początku traktować jako jedną z najbardziej charakterystycznych cech izraelskiego systemu wyborczego.

stytucji demokracji bezpośredniej, gdyż Kneset mógłby zadecydować, w ramach realizowanej przez parlament funkcji ustawodawczej, o rozstrzygnięciu określonej sprawy w drodze ogólnokrajowego referendum.

10 W Izraelu nie zdecydowano się przede wszystkim na przeprowadzanie bezpośrednich wyborów prezydenckich i tym samym od początku prezydent był powoływany przez parlament. Do 2000 r. prezydent był wybierany na pięć lat i ta sama osoba mogła pełnić ten urząd przez dwie kolejne kadencje. Znowelizowana wówczas Ustawa zasadnicza o Prezydencie Państwa z 1964 r. przyjęła jednak zasadę, że prezydent Izraela ma być wybierany przez Kneset na siedmioletnią kadencję bez możliwości reelekcji.

11 Zasady prawa wyborczego do izraelskiego parlamentu określone zostały w Ustawie zasadniczej o Knesecie, a szczegółowy tryb przeprowadzania wyborów uregulowała ustawa o wyborach do Knesetu z 1969 roku.

12 Zob. szerzej A. Diskin, Elections and Voters in Israel, New York 1991, s. 43 i n.; G. Rahat, R. Y. Hazan, Israel: The Politics of an Extreme Electoral System, (w:) M. Gallagher, P. Mitchell (red.), The Politics of Electoral Systems, Oxford 2005, s. 333 in. 
W Izraelu prawo zgłaszania list kandydatów przyznano wyłącznie partiom politycznym, przy czym każda partia zgłasza jedną listę w skali całego kraju. ${ }^{13} \mathrm{~W}$ tym zakresie konieczne było jednak wprowadzenie pewnych ograniczeń. Miały one na celu wyeliminowanie $\mathrm{z}$ udziału w wyborach do Knesetu ugrupowań politycznych godzących w zasady demokracji bądź też poważnie zagrażających bezpieczeństwu państwa i jego obywateli. Znowelizowana w 1985 r. Ustawa zasadnicza o Knesecie przyjęła więc zasadę (art. 7A), że do wyborów nie mogą być dopuszczone listy kandydatów tych organizacji, które: 1) negują istnienie Państwa Izrael jako państwa żydowskiego, 2) negują demokratyczny charakter państwa, 3) nawołują do rasizmu. ${ }^{14}$

System wyborczy do Knesetu charakteryzuje się niezmiennie także tym, że podczas aktu głosowania każdy wyborca oddaje swój głos na jedną ze zgłoszonych list kandydatów, a więc nie ma możliwości wyboru określonego kandydata z danej listy. Liczba głosów oddanych na poszczególne listy stanowi podstawę podziału mandatów, przy czym w podziale tym mogą uczestniczyć jedynie te listy kandydatów, które w skali całego kraju zebrały co najmniej 1,5\% ważnie oddanych głosów. Ta niewysoka klauzula zaporowa, w połączeniu z proporcjonalnym systemem podziału mandatów metodą Sainte-Laguë, okazała się w praktyce bardzo korzystna dla niewielkich partii politycznych, bo umożliwiła im nieprzerwanie przynajmniej minimalną reprezentację $\mathrm{w}$ parlamencie. ${ }^{15}$ Stosowana w Izraelu metoda podziału mandatów sprawiła, że w kolejnych wyborach parlamentarnych procentowy odsetek posłów każdej partii w składzie Knesetu odpowiadał w przybliżeniu skali poparcia udzielonego przez wyborców dla listy tej partii.

\section{Układ sił politycznych w Knesecie a tworzenie rządu}

Na rezultaty wyborów parlamentarnych w Izraelu istotny wpływ wywierał od początku funkcjonujący w tym państwie system partyjny. ${ }^{16}$ Mimo daleko idących podziałów między poszczególnymi partiami, przez wiele lat nie było problemów $\mathrm{z}$ tworzeniem w miarę stabilnej większości rządowej. Po utworzeniu Izraela status najsilniejszego ugrupowania politycznego utrzymywała długo lewicowa Robotnicza

\footnotetext{
13 Te partie, które posiadają reprezentację w składzie Knesetu mijającej kadencji, mogą rejestrować swoje listy bez żadnych dodatkowych warunków, natomiast listy innych partii politycznych muszą być poparte podpisami co najmniej 2500 wyborców. Kandydaci umieszczani są na listach w kolejności ustalanej każdorazowo przez naczelne władze partyjne. Najwyższe pozycje na listach kandydatów, a więc gwarantujące z reguły uzyskanie mandatu deputowanego, otrzymują czołowi politycy poszczególnych partii politycznych.

14 Por. S. Navot, The Constitution of Israel. A Contextual Analysis, Oxford 2014, s. 101 i n.

15 Zob. D. Peretz, The Government and Politics of Israel, Boulder 1979, s.166 i n.; A. Diskin, Elections..., op. cit., s. $177 \mathrm{in}$.

16 Zarazem jednak przyjęty proporcjonalny system wyborczy do Knesetu determinował stale kształt izraelskiego systemu partyjnego, w którym nie doszło do wykształcenia się, tak jak w klasycznych systemach dwupartyjnych, dwóch wyraźnie dominujących ugrupowań politycznych. Por. G. Sheffer, Political Change and Party System Transformation, (w:) R. Y. Hazan, M. Maor (ed.), Parties, Elections and Cleavages: Israel in Comparative and Theoretical Perspective, London 2000, s. 149 i n.
} 
Partia Izraela (Mapai). ${ }^{17} \mathrm{~W} 1968$ r., po przyłączeniu do niej kilku małych ugrupowań, przyjęła ona nazwę Partia Pracy (Mifleget HaAvoda). Partii tej nigdy nie udało się jednak zebrać ponad połowy głosów w wyborach parlamentarnych i w ten sposób zapewnić sobie bezwzględnej większości mandatów poselskich w Knesecie. Stąd też była ona zmuszona tworzyć każdorazowo koalicje rządowe z dużo mniejszymi partiami politycznymi. ${ }^{18}$ Partia Pracy (do 1968 r. Mapai) uczestniczyła nieprzerwanie we wszystkich koalicjach rządowych, jakie były formowane w latach 1949-1977, pełniąc w nich niezmiennie wyraźnie dominującą rolę.

Tak znaczące sukcesy socjaldemokratów były wynikiem utrzymującego się przez wiele lat poważnego rozbicia politycznego izraelskiej prawicy. Dopiero w 1973 r. wszystkie liczące się ugrupowania prawicowe utworzyły wspólny blok Zjednoczenie (Likud), który stał się od razu alternatywą polityczną dla gabinetów zdominowanych przez partię socjaldemokratyczną. Po raz pierwszy Likud wygrał wybory parlamentarne w 1977 r., tworząc koalicję rządową o charakterze prawicowym. Koalicja ta utrzymała się u władzy w latach 1977-1984, posiadając jednak wówczas tylko minimalną przewagę w Knesecie nad ugrupowaniami politycznymi opozycji parlamentarnej. ${ }^{19}$

Szczególne trudności z wyłonieniem stabilnej większości rządowej pojawiły się w Izraelu po wyborach do Knesetu z 1984 r. Wybory te zakończyły się sukcesem Partii Pracy, która wywalczyła 44 mandaty, ale niewiele gorszy wynik (41 mandatów) osiągnął Likud. Poza tymi dwiema partiami, swoich przedstawicieli do Knesetu wprowadziło jeszcze 12 ugrupowań, ale żadne $\mathrm{z}$ nich nie było wówczas w stanie zdobyć więcej niż 4 mandaty. ${ }^{20} \mathrm{~W}$ konsekwencji nastąpiła daleko idąca dekompozycja składu politycznego parlamentu, uniemożliwiająca praktycznie stworzenie koalicji zdolnej do rządzenia. Najbardziej rozsądnym rozwiązaniem stało się wówczas utworzenie przez oba najsilniejsze ugrupowania polityczne wspólnej koalicji rządowej. ${ }^{21}$ Rządy tzw. wielkiej koalicji, określane również jako rządy ,jedności narodowej”, sprawowane były w Izraelu do 1990 roku. ${ }^{22}$

Za główną przyczynę poważnego rozdrobnienia politycznego parlamentu zaczęto wtedy uważać stosowanie proporcjonalnego systemu wyborczego, sprzyja-

17 Partia ta założona została w latach 30. XX wieku, a na jej czele stanął wówczas Dawid Ben Gurion, późniejszy pierwszy premier Izraela (1948-1954 i 1955-1963).

$18 \quad Z$ reguły były to koalicje lewicowo-centrowe, niekiedy także $z$ udziałem partii religijnych.

19 W wyborach z 1977 r. Likud zdobył 43 mandaty w Knesecie, natomiast Partia Pracy - 32. Kolejne wybory z 1981 r. dały obu najsilniejszym partiom politycznym niemal identyczny rezultat: Likud wywalczył 48 mandatów, Partia Pracy zaś 47. Por. S. Bożyk, System konstytucyjny..., op. cit. s. 79.

20 Tak znacznego rozbicia politycznego izraelskiego parlamentu, liczącego przecież tylko 120 deputowanych, nie było od 1948 roku. Rozbicie wielopartyjne miało stać się już trwałym zjawiskiem na scenie politycznej Izraela. Zob. G. Sheffer, Political Change..., op. cit., s. 161 i n.

21 O okolicznościach utworzenia i funkcjonowaniu tej koalicji zob. N. Lochery, The Israeli Labour Party: in the shadow of the Likud, London 1997, s. 195 i n.

22 Niemal identyczną liczbę mandatów oba najsilniejsze ugrupowania zdobyły też w wyborach parlamentarnych z 1988 r.: Likud - 40, Partia Pracy - 39. Swoich reprezentantów wprowadziło wtedy do Knesetu także 14 małych partii politycznych, a więc jeszcze więcej, aniżeli cztery lata wcześniej. 
jącego niewielkim partiom politycznym. ${ }^{23}$ Nie przypadkowo więc podczas rządów „wielkiej koalicji” pojawiły się głosy wskazujące na konieczność dokonania zmian $\mathrm{w}$ istniejącym systemie wyborczym. Potrzeba reformy prawa wyborczego stała się oczywista zwłaszcza w obliczu rozpadu rządu jedności narodowej, do czego doszło w marcu 1990 r. Z wielkim trudem uformowano wówczas nową koalicję rządową, składającą się z Likudu oraz kilku małych partii religijnych. Wewnątrz tej koalicji dochodziło jednak bardzo często do poważnych sporów i podziałów, co doprowadziło ostatecznie do rozłamu w jej szeregach w styczniu 1992 r. Rząd Icchaka Szamira stał się w ten sposób gabinetem mniejszościowym, niezdolnym do dalszego funkcjonowania, ${ }^{24}$ wskutek czego musiały być zarządzone przedterminowe wybory do Knesetu.

\section{Wprowadzenie bezpośrednich wyborów premiera}

Zanim doszło w 1992 r. do skrócenia kadencji parlamentu, na nowo rozgorzała dyskusja nad potrzebą reformy prawa wyborczego. Pojawiło się wówczas kilka propozycji zmian w praktykowanym dotąd w Izraelu proporcjonalnym systemie wyborczym, ${ }^{25}$ ale z największym zainteresowaniem spotkał się projekt przyjęcia formuły powszechnych oraz bezpośrednich wyborów premiera. Pomysłodawcy takiego rozwiązania wskazywali, że wprowadzenie go do ustroju politycznego Izraela pozwoli na osłabienie negatywnych skutków stosowania zasady proporcjonalności w wyborach parlamentarnych, a zwłaszcza ograniczy rozbicie polityczne Knesetu oraz zdecydowanie usprawni proces tworzenia rządu. Bezpośrednie wybory szefa rządu miały także wzmocnić jego legitymację do rządzenia oraz pozycję ustrojową, a przy tym zwiększyć rangę gabinetu w strukturze naczelnych organów państwowych. ${ }^{26} \mathrm{Jak}$ się wkrótce okazało, reforma izraelskiego prawa wyborczego ograniczyć się miała $\mathrm{w}$ zasadzie jedynie do ukształtowania systemu elekcji na urząd premiera w drodze wyborów powszechnych i bezpośrednich.

Nie znaczy to oczywiście, że wszystkie liczące się w Izraelu ugrupowania polityczne były skłonne do poparcia tej reformy ustrojowej. Od początku przeciwko wprowadzeniu systemu elekcji premiera w drodze wyborów opowiadał się przede wszystkim Likud, w tym stojący na czele rządu przywódca tego ugrupowania I. Szamir. W toku prac parlamentarnych nad zmianą ustawodawstwa premier nalegał na wprowadzenie ostrej dyscypliny partyjnej i zobowiązanie wszystkich posłów do głosowania przeciwko reformie. Ostatecznie jednak I. Szamir tuż przed głosowaniem w Knesecie zmienił zdanie i wyraził zgodę na to, aby członkowie Likudu mogli

Zob. szerzej G. Doron, M. Harris, Public Policy and Electoral Reform: The Case of Israel, Boston 2000, s. 82 i n.

Zob. szerzej G. Goldberg, HaBocher HaYisraeli, 1992 (The Israeli Voter, 1992), Jerusalem 1994 (hebr.).

Por. G. Rahat, R. Y. Hazan, Israel: The Politics..., op. cit., s. 342 i n.

Szerzej na temat przesłanek tej reformy systemu wyborczego w Izraelu zob. H. Diskin, A. Diskin, The Politics of Electoral Reform in Israel, „International Political Science Review” 1995, Vol. 16, No 1, s. 31 i n. 
głosować zgodnie z własnym sumieniem, a nie kierować się ustaleniami podjętymi wcześniej przez kierownictwo partii. ${ }^{27}$

Wprowadzenie bezpośrednich wyborów premiera wymagało zmian w treści obowiązującej Ustawy zasadniczej o Rządzie z 1968 r., gdyż jej przepisy określały procedurę powoływania rządu. Izraelski parlament zdecydował się jednak na uchwalenie nowej Ustawy zasadniczej o Rządzie, która przyjęta została przez Kneset w dniu 18 marca 1992 r. ${ }^{28}$ W rzeczywistości duża część przepisów poprzedniej ustawy zasadniczej znalazła się bez żadnych zmian w tekście nowego aktu ustrojowego. Całkowicie nowe unormowania odnosiły się do trybu organizacji i przeprowadzania powszechnych i bezpośrednich wyborów premiera. Zmienione zostały także przepisy określające procedurę kształtowania składu rządu, zasady jego odpowiedzialności oraz wzajemne relacje między egzekutywą a innymi organami państwowymi Izraela. Należy jeszcze dodać, że przyjęcie zasady elekcji premiera bezpośrednio przez obywateli wymagało też dokonania zmian w treści innych aktów ustrojowych, a zwłaszcza w Ustawie zasadniczej o Knesecie.

Przewidziana w nowej Ustawie zasadniczej o Rządzie procedura powoływania premiera w wyborach powszechnych i bezpośrednich miała mieć zastosowanie dopiero wraz z wyborami do Knesetu kolejnej kadencji. Najbliższe wybory parlamentarne w czerwcu 1992 r. nie były jeszcze powiązane z jednoczesną, bezpośrednią elekcją szefa rządu. Wynik tych wyborów do Knesetu zdawał się potwierdzać słuszność przeprowadzonej reformy systemu wyborczego, której efekty miały przynieść, jak zakładano, już następne wybory do parlamentu. ${ }^{29}$ Sukces odniosła wtedy Partia Pracy (44 mandaty), ale do utworzenia rządu konieczne było podpisanie porozumienia koalicyjnego z dwoma innymi ugrupowaniami: Merec (ukształtowanej przed wyborami z 1992 r. koalicji wyborczej lewicy laickiej) i Szas (partii ortodoksyjnych Żydów Sefardyjskich). W ten sposób powstała, licząca w sumie 62 mandaty, większość rządowa w Knesecie, a na czele gabinetu stanął lider Partii Pracy Icchak Rabin. ${ }^{30}$ Była to większość w miarę stabilna, bowiem utrzymała się przez całą kadencję parlamentu (1992-1996), ${ }^{31}$ niemniej jednak w Knesecie istniało nadal daleko idące rozbicie polityczne. ${ }^{32}$

27 Por. G. S. Mahler, Kneset. Parlament w systemie politycznym Izraela, Warszawa 1996, s. 189.

28 Przyjęcie tej ustawy zasadniczej oznaczało uchylenie w całości poprzedniej ustawy zasadniczej z 1968 roku.

29 Por. G. Doron, B. Kay, Reforming Israel's Voting Schemes, (w:) A. Arian, M. Shamir (red.), The Elections in Israel - 1992, Albany 1995, s. 299 i n.

30 Premier I. Rabin mógł też liczyć na poparcie ze strony kilku posłów arabskich, ale pod warunkiem kontynuacji przez jego rząd procesu pokojowego na Bliskim Wschodzie.

31 Premier I. Rabin w 1995 r. został zamordowany przez żydowskiego fanatyka religijnego, więc na czele rządu stanał Szimon Peres.

32 W wyborach z 1992 r. swoich reprezentantów, poza ugrupowaniami koalicyjnymi, wprowadziło do Knesetu jeszcze 10 innych partii politycznych, w tym Likud (32 mandaty), który przez poprzednich 15 lat przewodził kolejnym koalicjom rządowym. 


\section{Bezpośrednie wybory premiera a system rządów}

Należy podkreślić, że procedura tworzenia izraelskiego rządu, jak też jego organizacja i tryb funkcjonowania, praktycznie aż do 1968 r. oparte były w dużym stopniu na zasadach zwyczajowych, wywodzących się wyraźnie z brytyjskich konwenansów konstytucyjnych, które miały zastosowanie w działalności administracji mandatowej na obszarze Palestyny. Niektóre z tych zwyczajów, jak chociażby praktyka powoływania premiera wyłącznie z grona deputowanych do parlamentu, doczekały się później formalnej regulacji w postanowieniach kolejnych ustaw zasadniczych. ${ }^{33}$ Po raz pierwszy szczegółowe unormowania prawne trybu powoływania, pozycji ustrojowej, struktury oraz zakresu uprawnień rządu Izraela znalazły się dopiero w Ustawie zasadniczej o Rządzie z 1968 r.

W kwestii procedury powoływania rządu ustawa zasadnicza z 1968 r. przyjęła zasadę, że rozpoczyna się ona od desygnowania przez prezydenta kandydata na stanowisko premiera. Powołany przez głowę państwa premier przystępował następnie do kształtowania składu rządu. Po uformowaniu gabinetu premier przedstawiał Knesetowi jego skład i program działania wraz $\mathrm{z}$ wnioskiem o udzielenie mu wotum zaufania. Dopiero po uzyskaniu wotum zaufania ze strony parlamentu rząd przystępował do wykonywania swoich konstytucyjnych obowiązków w zakresie władzy wykonawczej. ${ }^{34}$

Wprowadzając w 1992 r. do systemu konstytucyjnego Izraela zasadę powszechnych i bezpośrednich wyborów premiera, ustrojodawca starał się jednocześnie utrzymać istniejący dotąd $\mathrm{w}$ tym państwie system rządów parlamentarnych. W konsekwencji tak istotna reforma prawnoustrojowa nie doprowadziła do radykalnych przekształceń we wzajemnych relacjach między władzą ustawodawczą a organami egzekutywy. Warto w związku z tym zaznaczyć, że układ stosunków między parlamentem a rządem kształtowano już od 1949 r. zgodnie z regułą przewidującą, że szczególnie istotnym obowiązkiem Knesetu ma być „wyłonienie” rządu zdolnego do podejmowania skutecznej działalności w sferze władzy wykonawczej. ${ }^{35}$ Przyjęto wobec tego zasadę, że skład rządu powoływany będzie co prawda przez prezydenta, ale z uwzględnieniem istniejącego układu sił politycznych w parlamencie. Rząd miał ponosić odpowiedzialność polityczną przed parlamentem, a tym samym Kneset mógł w dowolnym momencie uchwalić wotum nieufności i doprowadzić w ten sposób do dymisji rządu.

Zasada odpowiedzialności politycznej premiera i w konsekwencji całego gabinetu została utrzymana po zmianie w 1992 r. trybu obsady szefa rządu, ale zmieniły się formy oraz skutki egzekwowania tej odpowiedzialności. Nowa Ustawa zasadnicza o Rządzie przewidywała w art. 19, że „Kneset może uchwalić wotum nieufno-

Zob. D. Peretz, The Government..., op. cit., s. 144 i n.

Por. E. Likhovski, Israel's Parliament, Oxford 1971, s. 125 i n.

Zob. m.in. S. Navot, Constitutional Law..., op. cit., s. 128 i n. 
ści dla premiera głosami większości swoich członków”. Ten sam przepis stanowił ponadto, że: „Uchwalenie wotum nieufności uważa się za równoznaczne z decyzją Knesetu o rozwiązaniu się przed upływem kadencji”. Przyjęcie takiej regulacji oznaczało, że uchwalenie przez Kneset wotum nieufności premierowi i jego rządowi miało prowadzić do rozwiązania parlamentu oraz konieczności przeprowadzenia przedterminowych wyborów parlamentarnych i premiera. ${ }^{36}$

\section{Zasady bezpośrednich wyborów premiera}

Zasadę wyboru premiera Izraela przez ogół obywateli ${ }^{37}$ określono w treści art. 3 Ustawy zasadniczej o Rządzie z 1992 r., stanowiącym: „Premier sprawuje urząd na podstawie wyboru w wyborach ogólnokrajowych, powszechnych, bezpośrednich i równych, przeprowadzanych w głosowaniu tajnym”. W celu konkretyzacji tych ogólnych zasad wyboru szefa rządu przepis art. 3 odsyłał do innych aktów normatywnych, w tym zwłaszcza do postanowień Ustawy zasadniczej o Knesecie. ${ }^{38}$

Określając ramy czynnego prawa wyborczego, przepis art. 6 Ustawy zasadniczej o Rządzie przewidywał, że prawo głosowania w powszechnych i bezpośrednich wyborach premiera będzie przysługiwało wszystkim osobom ,posiadającym prawo głosowania w wyborach do Knesetu". Zgodnie z art. 4 Ustawy zasadniczej o Knesecie prawo to przyznane zostało wszystkim obywatelom Izraela, którzy ukończyli 18 lat, ale pod warunkiem, że nie zostali pozbawieni tego prawa decyzją sądu.

Zakres biernego prawa wyborczego określono w art. 8 Ustawy zasadniczej o Rządzie. Na podstawie tego przepisu na urząd premiera Izraela mogły kandydować jedynie te osoby, które spełniały następujące warunki: 1) posiadały bierne prawo wyborcze do Knesetu i ukończyły 30 lat w dniu zgłoszenia kandydatury, ${ }^{39} 2$ ) zostały umieszczone na pierwszym miejscu na liście kandydatów do Knesetu, jeżeli wybory premiera odbywały się jednocześnie z wyborami parlamentarnymi, 3) byli członkami Knesetu, gdy przeprowadzano odrębne wybory premiera. Art. 8 przewidywał także, że polityk, który sprawował urząd premiera przez siedem kolejnych lat, nie mógł już kandydować na tę funkcję w kolejnych wyborach.

W art. 4 Ustawy zasadniczej o Rządzie przyjęta została zasada, że premier Izraela będzie wybierany, poza szczególnymi sytuacjami, równocześnie z wyborami do Knesetu. Oznaczało to, że instytucja zarządzania wyborów będzie mogła być stoso-

\footnotetext{
36 Takie same konsekwencje przewidziane zostały (w art. 20 Ustawy zasadniczej o Rządzie) na wypadek, gdyby parlament nie uchwalił w ustawowym terminie „trzech miesięcy od początku roku budżetowego” nowej ustawy budżetowej.

37 Problematyka prawnoustrojowej regulacji procedury wyborów na urząd premiera Izraela doczekała się wielu wnikliwych studiów, zarówno w samym Izraelu, jak też w państwach zachodnich. Zob. np. A. Brichta, Political Reform in Israel: The Quest for Stable and Effective Government, Brighton 2001; G. Doron (red.), HaMahapecha HaElectoralit (The Electoral Revolution), Tel Aviv 1996 (hebr.). o Knesecie oraz w ustawodawstwie zwykłym, znalazło zastosowanie także przy organizacji wyborów premiera. Bierne prawo wyborcze w wyborach do Knesetu przysługuje obywatelom Izraela, którzy ukończyli 21 lat.
} 
wana jedynie sporadycznie (np. gdy wybory będą musiały być powtórzone w wyniku protestów wyborczych), gdyż wybory parlamentarne w Izraelu przeprowadzane są zwykle w terminach określonych przez przepisy obowiązujących ustaw zasadniczych. Gdy dobiega końca pełna kadencja parlamentu, wybory odbywają się zawsze $\mathrm{w}$ trzeci wtorek miesiąca cheszwan, ${ }^{40}$ przypadający w tym roku, w którym upływa kadencja Knesetu. Kiedy jednak rok wyborczy był poprzedzony rokiem przestępnym ${ }^{41}$ wówczas wybory przeprowadza się w pierwszy wtorek miesiąca cheszwan. Aby umożliwić udział w głosowaniu jak największej liczbie wyborców i tym samym zagwarantować realizację zasady powszechności wyborów, Ustawa zasadnicza o Knesecie wprowadziła zasadę (art. 10), że dzień głosowania ma być dniem wolnym od pracy. Z kolei w art. 11 Ustawy zasadniczej o Rządzie przewidziano, że gdyby dzień wyborów do Knesetu oraz wyborów premiera wypadał w dniu wolnym od pracy, dniu poprzedzającym dzień wolny od pracy lub w dniu następującym po dniu wolnym od pracy, wybory miały być przeprowadzane w pierwszy kolejny wtorek, zarządzany wtedy dniem wolnym dla wszystkich pracowników.

Niezależnie od łącznych wyborów do Knesetu i na stanowisko szefa rządu przewidywano też odrębne wybory premiera. System elekcji w wyborach odrębnych mógł być zastosowany jedynie wtedy, gdy: 1) żaden kandydat nie został wybrany w wyborach przeprowadzanych łącznie z wyborami do Knesetu, 2) niepowodzeniem zakończyła się próba utworzenia rządu przez premiera wybranego w łącznych wyborach, 3) liczba ministrów w istniejącym rządzie spadła poniżej ośmiu, ${ }^{42} 4$ ) nastąpiło opróżnienie urzędu premiera $\mathrm{z}$ powodu śmierci, zrzeczenia się funkcji lub złożenia z urzędu decyzją parlamentu. W wyborach odrębnych mogli oczywiście kandydować jedynie członkowie Knesetu.

Ustawa zasadnicza o Rządzie w art. 9 przyznała prawo zgłaszania kandydatów na urząd premiera: 1) partiom politycznym oraz koalicjom partyjnym, które zgłosiły listy kandydatów w wyborach do Knesetu i są reprezentowane w Knesecie kończącym kadencję przez frakcje partyjne liczące co najmniej 10 deputowanych, 2) innym partiom politycznym, które zgłosiły listy kandydatów w wyborach do Knesetu poparte podpisami 50000 wyborców. W wyborach odrębnych przewidziano natomiast możliwość zgłaszania kandydatów przez: 1) ugrupowania polityczne reprezentowane w Knesecie i posiadające frakcje partyjne liczące co najmniej 10 członków, 2) koalicje partyjne reprezentowane w Knesecie przez frakcje, które składają się z co najmniej 10 deputowanych.

Warunkiem wyboru na urząd premiera, określonym w przepisie art. 13 Ustawy zasadniczej o Rządzie, było uzyskanie przez jednego z kandydatów ponad połowy

40 Jest to $w$ kalendarzu hebrajskim ósmy miesiąc roku księżycowego, rozpoczynający się zazwyczaj pod koniec października.

41 Ze względu na to, że liczący 354 dni rok księżycowy w kalendarzu hebrajskim jest o 11 dni krótszy od roku słonecznego, 7 razy w ciągu 19 lat wprowadza się rok przestępny z dodatkowym miesiącem.

42 Zgodnie z art. 33 Ustawy zasadniczej o Rządzie z 1992 r. liczba członków rządu nie mogła być mniejsza od ośmiu ani większa od osiemnastu. 
ważnie oddanych głosów. Przewidziano przy tym spełnienie jeszcze jednego warunku, a mianowicie kandydat na premiera musiał być jednocześnie wybrany do składu Knesetu. Gdyby żaden z kandydatów nie spełnił tych wymogów, miała być przeprowadzana druga tura głosowania z udziałem dwóch kandydatów, którzy zebrali najwięcej głosów w pierwszej turze. ${ }^{43}$ Zwyciężał w niej ten kandydat, na którego oddano większą liczbę głosów ważnych. Wybrany w taki sposób premier-elekt przystępował następnie do powoływania ministrów i występował do Knesetu o udzielenie jego rządowi wotum zaufania. Gdyby jednak premier-elekt nie zdołał tego uczynić w terminie przewidzianym przez ustawę zasadniczą, ${ }^{44}$ powstałaby konieczność zarządzenia przez prezydenta ponownych wyborów na urząd premiera. ${ }^{45}$ Z kolei w sytuacji, kiedy Kneset odmówiłby udzielenia wotum zaufania premierowi oraz jego gabinetowi, parlament podlegał rozwiązaniu i musiałyby być przeprowadzone ponowne wybory parlamentarne oraz wybory szefa rządu.

Przepisy Ustawy zasadniczej o Rządzie przewidywały również kilka sytuacji, w których konieczne było przeprowadzenie przedterminowych wyborów na urząd premiera. Należało je zarządzić chociażby wtedy, o czym już wcześniej wspominałem, gdy Kneset udzielił szefowi rządu i jego gabinetowi wotum nieufności lub nie uchwalił w terminie ustawy budżetowej, co traktowane było za równoznaczne z decyzją Knesetu o samorozwiązaniu przed upływem kadencji parlamentu. Przedterminowe wybory premiera miały być poza tym przeprowadzane $\mathrm{w}$ konsekwencji: 1) śmierci premiera, 2) zrzeczenia się przez premiera sprawowanego urzędu, 3) uznania niezdolności premiera do sprawowania urzędu przez okres dłuższy aniżeli 100 dni, 4) podjęcia przez Kneset decyzji o pozbawieniu premiera zajmowanego stanowiska. ${ }^{46} \mathrm{Na}$ osobną uwagę zasługuje jeszcze jedna okoliczność, która również skutkowała koniecznością przeprowadzenia przedterminowych wyborów szefa rządu. Była nią, przewidziana w art. 22 Ustawy zasadniczej o Rządzie, możliwość rozwiązania Knesetu przez urzędującego premiera, z której mógł on jednak skorzystać jedynie w szczególnych okolicznościach i tylko za zgodą, prezydenta. Na podstawie tego przepisu ustawy zasadniczej premierowi przysługiwało prawo zarządzenia rozwiązania Knesetu wyłącznie w sytuacji, kiedy dochodził on do przekonania, iż

\footnotetext{
43 W sytuacji, kiedy w pierwszej lub drugiej turze pozostałby tylko jeden kandydat, warunkiem wyboru go na urząd premiera było uzyskanie przez niego więcej głosów za aniżeli przeciwko kandydaturze.

44 W art. 14 Ustawy zasadniczej o Rządzie przewidziano, że premier-elekt będzie miał 45 dni od dnia ogłoszenia wyników wyborów na powołanie składu rządu i przedłożenie w Knesecie wniosku o udzielenie temu rządowi wotum zaufania.

45 Ponowne wybory premiera miały być wówczas przeprowadzone w terminie 60 dni od ich zarządzenia przez prezydenta.

46 Taką możliwość przewidywały dwa przepisy Ustawy zasadniczej o Rządzie. Art. 26 stwierdzał, że: „Jeżeli premier został skazany za przestępstwo z niskich pobudek, Kneset może złożyć go z urzędu decyzją przyjętą przez większość członków Knesetu". Z kolei w art. 27 przyjęta została zasada, że na wniosek złożony przez co najmniej czterdziestu deputowanych „Kneset może złożyć premiera z urzędu w drodze uchwały przyjętej przez co najmniej osiemdziesięciu członków Knesetu".
} 
większość deputowanych do parlamentu znalazła się w opozycji wobec gabinetu i że wskutek tego nie będzie już możliwe skuteczne funkcjonowanie rządu. ${ }^{47}$

\section{Bezpośrednie wybory premiera w praktyce ustrojowej Izraela}

Wprowadzony przez Ustawę zasadniczą o Rządzie z 1992 r. system obsady stanowiska premiera $\mathrm{w}$ drodze wyborów powszechnych i bezpośrednich zastosowano w Izraelu jedynie trzykrotnie. W 1996 i 1999 r. wybory premiera odbyły się łącznie z wyborami do Knesetu, zaś w 2001 r. nie zostały zarządzone wybory parlamentarne i przeprowadzono tylko odrębne wybory na urząd szefa egzekutywy. ${ }^{48}$ Był to więc w sumie bardzo krótki, ale bez wątpienia interesujący eksperyment w odniesieniu do procedury wyłaniania szefa egzekutywy.

Po raz pierwszy powszechne wybory premiera przeprowadzone zostały w Izraelu w dniu 29 maja 1996 r. Było to niewątpliwie wydarzenie historyczne, bowiem nigdy wcześniej taka forma elekcji szefa rządu nie miała zastosowania w żadnym systemie ustrojowym. ${ }^{49}$ Do walki o fotel premiera zgłoszeni zostali wówczas dwaj kandydaci: urzędujący premier Szimon Peres (Partia Pracy) oraz Binjamin Netanjahu (Likud). Wybory te wygrał nieznacznie B. Netanjahu (50,5\% głosów), pokonując faworyzowanego Sz. Peresa (49,5\% głosów). ${ }^{50} \mathrm{O}$ zwycięstwie lidera Likudu zadecydowało prawdopodobnie to, że w kampanii wyborczej opowiadał się on za powstrzymaniem nadmiernych ustępstw wobec Palestyńczyków, które przypisywał przede wszystkim swojemu konkurentowi, a zarazem dotychczasowemu premierowi.

W przeprowadzonych równolegle wyborach do Knesetu najwięcej głosów oraz mandatów wywalczyło dla odmiany ugrupowanie Sz. Peresa. Partia Pracy zdobyła w wyborach z 1996 r. 34 mandaty, Likud zaś 32 mandaty. Jak się okazało, poważna część wyborców głosujących na jednego z kandydatów na premiera oddawała swoje głosy na mniejsze ugrupowania walczące o miejsca w parlamencie. W konsekwencji kolejno największą liczbę mandatów w Knesecie zdobyli: Sefardyjscy Strażnicy Tory (Szas) - 10, Narodowa Partia Religijna (Mafdal) - 9 oraz Merec - 9. Znaczny wzrost poparcia (7 mandatów) zanotowało ugrupowanie o charakterze prawicowo-

47 W 2000 r. premier Ehud Barak nie zdecydował się ostatecznie na rozwiązanie Knesetu, mimo zaistnienia przesłanek prawnych podjęcia takiej decyzji. Podał się natomiast do dymisji, co pozwoliło oczywiście uniknąć przedterminowych wyborów parlamentarnych. W 2001 r. odbyły się więc jedynie odrębne wybory na urząd premiera Izraela.

48 Szczegółową analizę trzech kolejnych bezpośrednich elekcji premiera Izraela zob. w opracowaniu A. Diskin, The Last Days in Israel: Understanding the New Israeli Democracy, Portland-Oregon 2003.

49 Por. R. Y. Hazan, G. Rahat, Representation, Electoral Reform, and Democracy. Theoretical and Empirical Lessons From the 1996 Elections in Israel, „Comparative Political Studies” 2000, Vol. 33 No 10, s. 1310 i n.

50 Zob. m.in. A. Arian, The Israeli Election for Prime Minister and the Knesset, 1996, „Electoral Studies” 1996, Vol. 15 No 4, s. 570 i n.; R. Y. Hazan, Presidential Parlamentarism: Direct Popular Election of the Prime Minister, Israel's New Electoral and Political System, „Electoral Studies” 1996, Vol. 15, No 1, s. 21 i n. 
nacjonalistycznym pod nazwą Izrael Nasz Dom (Yisrael be-Alija), reprezentujące licznych emigrantów żydowskich, którzy w latach 1991-1995 przybyli do Izraela z krajów byłego Związku Radzieckiego. ${ }^{51}$ Po wyborach B. Netanjahu stworzył większościową koalicję rządową, do której weszły: Likud, Szas, Mafdal oraz Yisrael be-Alija.

Kolejne wybory premiera Izraela odbyły się w dniu 17 maja 1999 r. Tym razem również o ten urząd ubiegali się jedynie dwaj kandydaci: dotychczasowy premier Binjamin Netanjahu (Likud) oraz lider opozycyjnej Partii Pracy Ehud Barak. W wyborach z 1999 r. szef rządu poniósł wyraźną porażkę (43,9\% głosów), pokonany zdecydowanie przez E. Baraka, który zebrał 56,1\% głosów. ${ }^{52}$ Taki wynik wyborów nie był zaskoczeniem, gdyż błędy w polityce premiera B. Netanjahu (zwłaszcza w kwestii palestyńskiej) spowodowały wyraźny spadek notowań jego gabinetu.

Wraz z wyborami premiera przeprowadzono przedterminowe wybory do parlamentu. ${ }^{53}$ Te wybory spowodowały największe rozbicie polityczne Knesetu od czasu utworzenia Izraela, gdyż znaleźli się w nim przedstawiciele 15 ugrupowań politycznych. Najwięcej mandatów zdobyły: Partia Pracy - 26, Likud - 19, Szas - 17, Merec - 10 oraz Ysrael be-Alija - 6. Takie zróżnicowanie polityczne parlamentu przysporzyło poważne trudności w uformowaniu nowej koalicji rządowej i w konsekwencji do rządu E. Baraka weszli reprezentanci aż sześciu partii politycznych.

Po raz trzeci system powszechnej i bezpośredniej elekcji szefa egzekutywy zastosowano podczas wyborów z dnia 6 lutego 2001 r. Tym razem jednak, wskutek niespodziewanej rezygnacji E. Baraka $\mathrm{z}$ funkcji premiera $\mathrm{w}$ grudniu poprzedniego roku, ${ }^{54}$ odbyły się tylko odrębne wybory na urząd premiera. Wygrał je z ogromną przewagą (62,4\% głosów) lider Likudu Ariel Szaron, gdy tymczasem dotychczasowy premier E. Barak zdobył jedynie 37,6\% głosów wyborców. ${ }^{55}$ Po wyborach z 2001 r. doszło do utworzenia rządu ,jedności narodowej” z udziałem obu najsilniejszych w Izraelu ugrupowań politycznych. ${ }^{56}$ Utworzona z inicjatywy wybranego premiera A. Szarona koalicja Likudu oraz Partii Pracy utrzymała się, choć nie bez trudności, do 2005 roku. ${ }^{57}$

51 Szacuje się, że wówczas w ciągu kilku lat przybyło do Izraela (liczącego w 1990 r. niecałe 5 mln ludności) co najmniej 800000 imigrantów z republik byłego ZSRR.

52 Zob. R. Y. Hazan, A. Diskin, The 1999 Knesset and Prime Ministerial Elections in Israel, „Electoral Studies” 2000, Vol. 19 No 4, s. 628 in.

53 Przedterminowe wybory parlamentarne w Izraelu w 1999 r. były konsekwencją utraty poparcia dla polityki premiera B. Netanjahu przez większość deputowanych do Knesetu.

54 Premier E. Barak postanowił podać się do dymisji ze względu na to, że nie dysponował w parlamencie taką większością, która gwarantowałaby mu realizację procesu pokojowego na Bliskim Wschodzie. Liczył na to, że zapewni sobie większe poparcie członków Knesetu po ewentualnym i znaczącym sukcesie wyborczym.

55 Zob. A. Diskin, R. Y. Hazan, The 2001 Prime Ministerial Election in Israel, „Electoral Studies” 2002, Vol. 21 No 4 , s. 659 in.

56 Do utworzenia przez Likud oraz Partię Pracy (z udziałem dwóch innych partii politycznych) rządu ,jedności narodowej" przyczynił się głównie ponowny wybuch jesienią 2000 r. powstania palestyńskiego (Intifady) i związany z tym wzrost zagrożenia bezpieczeństwa państwa.

57 W 2005 r. A. Szaron opuścił Likud i założył nową partię prawicy pod nazwą Kadima (Naprzód), która wkrótce stała się trzecim znaczącym ugrupowaniem w systemie partyjnym Izraela. Por. S. Bożyk, Izrael, (w:) S. Bożyk, M. Grzybowski (red.), Systemy ustrojowe państw współczesnych, Białystok 2012, s. 256 i n. 


\section{Konsekwencje}

Nie ulega wątpliwości, że wprowadzenie w Izraelu w 1992 r. zasady powszechnych oraz bezpośrednich wyborów na urząd premiera było nowatorskim i interesującym eksperymentem ustrojowym. Powszechne wybory szefa egzekutywy nie doprowadziły jednak w praktyce do zamierzonych efektów. Taki sposób elekcji premiera nie doprowadził przede wszystkim do stabilizacji systemu partyjnego Izraela oraz przezwyciężenia rozbicia politycznego Knesetu. Co prawda, wyborcy oddawali swoje głosy na obu poważnych kandydatów ubiegających się o urząd premiera, ale jednocześnie - głosując w wyborach parlamentarnych - większość z nich udzielała swojego poparcia listom partyjnym zgłaszanym przez małe ugrupowania polityczne, mające potem skromną reprezentację w Knesecie. Bezpośrednie wybory premiera nie miały również w praktyce ustrojowej większego wpływu na umocnienie jego pozycji w strukturze naczelnych organów państwowych Izraela.

Nieprzypadkowo więc po wyborach powszechnych na urząd premiera z 6 lutego 2001 r., rząd Ariela Szarona (z inicjatywy obu najsilniejszych partii w koalicji rządowej) wystąpił z projektem zniesienia takiego systemu elekcji szefa egzekutywy. W konsekwencji Kneset uchwalił w dniu 7 marca 2001 r. nową Ustawę zasadniczą o Rządzie, odrzucającą obsadę stanowiska premiera bezpośrednio przez ogół obywateli. Wynikiem tego było ukształtowanie w tym istotnie zmienionym akcie ustrojowym takich rozwiązań prawnych, które oznaczały faktycznie powrót do zasad obsady urzędu premiera, stosowanych w Izraelu do 1992 roku.

\section{BIBLIOGRAFIA}

Arian A., The Israeli Election for Prime Minister and the Knesset, 1996, „Electoral Studies” 1996, Vol. 15 No 4

Arian A., Shamir M. (ed.), The Elections in Israel - 1992, Albany 1995

Bożyk S., Izrael, (w:) S. Bożyk. M. Grzybowski (red.), Systemy ustrojowe państw współczesnych, Białystok 2012

Bożyk S., System konstytucyjny Izraela, Warszawa 2002

Brichta A., Political reform in Israel: The Quest for Stable and Effective Government, Brighton 2001

Diskin A., Election and Voters in Israel, New York 1991

Diskin A., The Last Days in Izrael: Understanding the New Israeli Democracy, Portland- Oregon 2003

Diskin A., Hazan R. Y., The 2001 Prime Ministerial Election in Israel, „Electoral Studies” 2002, Vol. 21, No 4

Doron G., Harris M., Public Policy and Electoral Reform: The Case of Israel, Boston 2000

Elazar D. J. (ed.), Constitutionalism. The Israeli and American Experiences, Jerusalem 1990

Gallagher M., Mitchell P. (ed.), The Politics of Electoral Systems, Oxford 2005 
Hazan R. Y., Diskin A., The 1999 Knesset and Prime Ministerial Elections in Israel, „Electoral Studies” 2000, Vol. 19 No 4

Hazan R. Y., Maor M. (ed.), Parties, Elections and Cleavages: Israel in Comparative and Theoretical Perspective, London 2000

Mahler G. S., Kneset. Parlament w systemie politycznym Izraela, warszawa 1996

Navot S., Constitutional Law of Israel, Alphen aan den Rijn 2007

Navot S., The Constitution of Israel. A Contextual Analysis, Oxford 2014

Peretz D., The Government and Politics of Israel, Boulder 1979

The Constitution of the State of Israel 1996-5756, Jerusalem 1996 


\section{THE DIRECT ELECTION OF THE PRIME MINISTER IN ISRAEL'S CONSTITUTIONAL SYSTEM (1992-2001)}

In Israel, in the period from 1992 to 2001, for the first and only time in the history of modern democracies, the law was changed to enable direct elections for the prime minister. This was an attempt to circumvent weaknesses in the political system which were mostly attributed to the strict rule of proportional representation in electing the Knesset: a high degree of fragmentation and ideological polarisation of parliament, excessive power of small sectarian parties, lengthy processes of forming coalition governments, and the dysfunction of government and political institutions in general. Direct elections for the prime minister were supposed to increase stability, efficiency and legitimacy of the prime minister, government and political system. The reform was unsuccessful because the expectations of its creators - that the voters would adapt to the new institutional rules - failed to materialise. Instead of expressing undivided political loyalty to the prime ministerial candidate and his party, most voters divided their votes in the simultaneous elections for prime minister and parliament: the huge majority gave one vote to the candidate for prime minister of one of the two biggest parties, Labour Party or Likud, while the second vote was used massively to support small parties. The reform further deepened the crisis of the political system and produced numerous theoretical dilemmas about its nature.

Keywords: Israel, constitutional system, Knesset, prime minister, direct election, government, political parties

Słowa kluczowe: Izrael, system konstytucyjny, Kneset, premier, wybory beposrednie, partie polityczne 